\title{
Grasslands Advance tall fescue establishment and animal performance
}

\section{T.J. FRASER' and T.B. LYONS ${ }^{2}$ 'AgResearch, PO Box 60, Lincoln ${ }^{2}$ AgResearch, Private Bag 11008, Palmerston North}

\section{Abstract}

Tall fescue (Festuca arundinacea Schreb.) pastures in New Zealand have been considered to have slow establishment (Grasslands Roa) or lower summer quality (the faster establishing $\mathrm{AU}$ Triumph). Three experiments were conducted to study the establishment vigour, herbage production and animal growth rates of a new tall fescue cultivar, Grasslands Advance. Establishment vigour of Advance was similar to that of $\mathrm{Au}$ Triumph and $30 \%$ greater than that of Roa. Advance and AU Triumph were 17 and $8 \%$ higher in annual grass production than Roa, with Advance significantly out yielding the other two cultivars in the warm season. Animal performance per head of young sheep on Roa was significantly higher than on AU Triumph in spring, both Advance and Roa having a significant advantage over AU Triumph in the warm season.

Keywords: animal performance, Festucu urundinuceu, herbage production, pasture establishment, seedling vigour

\section{Introduction}

Tall fescue (Festuca arundinacea Schreb.) has for many years been recognised as having an important place in New Zealand pastoral farming systems. Once established, tall fescue will tolerate hot dry conditions and pasture pest attack (Kain et al. 1979; East et al. 1982; Prestidge et al. 1986); and it will also produce high quality leafy herbage over summer (Wright et al. 1985).

The use of tall fescue pastures has increased significantly over the last 10 years (McFarlane 1990; Milne \& Fraser 1990) but it still fails to meet its potential. This is thought to be mainly due to the slow establishment of Grasslands Roa (Brock et al. 1982; Woodman et al. 1990) and/or summer quality problems of $\mathrm{AU}$ Triumph, an imported American tall fescue. In an attempt to overcome these problems a lo-year breeding programme at AgResearch Grasslands concentrated on improving vigour at establishment while maintaining the forage quality of Roa and enhancing its seasonal regrowth (Easton \& Pennell 1993).
This paper reports on three trials set up to evaluate Grasslands Advance tall fescue, a new cultivar bred by AgResearch Grasslands.

\section{M ethods}

\section{Trial 1: Establishment}

This experiment was sown on an irrigated Wakanui silt loam at Lincoln in mid September 1992. Three replications of Grasslands Roa, Grasslands Advance and $\mathrm{AU}$ Triumph were sown in $20 \mathrm{~m}$ drill rows with an Oxford precision seed drill (9 coulters). Seeding rates were adjusted to sow 100 viable seeds per metre row (equivalent to $17 \mathrm{~kg} / \mathrm{ha}$ ). Six weeks after sowing, whole plants were harvested, counted, dried and total root and shoot growth weighed. Twelve 250-mm row lengths per plot were taken for this measurement.

\section{Trial 2: Herbage production}

This trial site was a free draining Manawatu fine sandy loam overlying medium - coarse sands and deep gravel. The trial area had been in grazed ryegrass and white clover plots for the previous 3 years and spray/fallowed over the summer until drilled with an Aitchison Seedmatic 800 into a lightly cultivated seedbed on 25th March 1992. Each of the tall fescue cultivars was sown into $145 \mathrm{~m}^{2}$ plots at a rate of $15.5 \mathrm{~kg} / \mathrm{ha}$, with Grasslands Kopu white clover at $3 \mathrm{~kg} / \mathrm{ha}$. The whole trial was lightly grazed at the end of July before all plots were individually fenced.

The trial design was a randomised block design consisting of 3 replicates of the 3 tall fescue cultivars. Grazing management was equivalent to 3-4 weekly grazings by young sheep during spring, summer and autumn, and 6-8 weekly in winter all to post grazing residual of $800-1000 \mathrm{~kg} / \mathrm{ha}$.

Herbage accumulation was measured prior to each grazing by cutting two $0.5 \mathrm{~m}^{2}$ quadrats per plot to 30 $\mathrm{mm}$, and a subsample was taken for determination of botanical composition. Post-grazing residuals were determined using a pasture probe. Soil tests taken before sowing indicated an Olsen $\mathrm{P}$ of $16 \mathrm{mg} / \mathrm{g}$. Annual autumn applications of $200 \mathrm{~kg} / \mathrm{ha}$ of $30 \%$ potassic superphosphate have increased Olsen $\mathrm{P}$ tests to $22 \mathrm{mg} / \mathrm{g}$. The initial $\mathrm{pH}$ of 5.6 has been maintained. 


\section{Trial 3: Animal performance}

This trial involved 4 tall fescue cultivars in a latin square design. For grazing, the trial was treated as a randomised block design with 2 replicates (effectively dividing the trial in half to give 2 animal replications). Cultivars were sown as pure species at $15 \mathrm{~kg} / \mathrm{ha}$ of viable seed in spring 1992 into an irrigated Templeton silt loam soil. Soil quick test parameters were $\mathrm{pH} 5.8, \mathrm{P}$ 12 and $\mathbf{S} 6$ at sowing.

Plots were $1000 \mathrm{~m}^{2}$ and were individually fenced. Over the first year the pastures were managed to ensure successful establishment. Animal measurements began in spring, 1993. Sheep were allocated to pastures to give similar herbage allowances per head. Extra, nontrial, animals were added if required to maintain equal allowances during the grazing periods. Two animal measurement periods are reported, spring 1993 (50 days) and summer and autumn 1993/94 (120 days).

Herbage mass, pre- and post-grazing was measured by a pasture probe. Trial periods started with a herbage mass of $2000 \mathrm{~kg} / \mathrm{ha}$ on the highest yielding pasture which was grazed down to about $700 \mathrm{~kg} / \mathrm{h}$ before moving the animals to the next pasture replication. All pastures were herbicide sprayed to maintain pure tall fescue swards. Nitrogen fertiliser ( $80 \mathrm{~kg} / \mathrm{ha}$ of urea) was applied 3 times a year. Maintenance superphosphate $(200 \mathrm{~kg} /$ ha) was applied in spring.

To maintain uniformity with the other 2 trials only the same 3 cultivars will be reported on from this trial.

\section{Results and Discussion}

For all trials, results are expressed as a percentage relative to the performance of Roa. Actual figures are included for Roa to give some level of general performance.

\section{Trial 1}

Seedling vigour of tall fescue can be influenced by the growing and harvest conditions of the seed crop (Easton \& Pennel11993). While it is recognised that this may have had some influence on the results from this trial when comparing the New Zealand cultivars to AU Triumph, the comparison between Advance and Roa is valid as both seed lines were grown and harvested under similar conditions (Easton pers. comm.).

There were no significant differences between seedling numbers (Table 1). However, seedling weight and total weight per unit area of Roa were significantly lighter than for AU Triumph and Advance. Seedling vigour has a major effect on subsequent establishment (Brock 1973: Woodman et al. 1990), and long-term production and persistence of pastures.
Table 1 Seedling numbers and establishment vigour.

\begin{tabular}{lcc}
\hline & Seedling numbers & Total weight \\
\hline Roa & 100 & 100 \\
Au Triumph & 103 & 123 \\
Advance & 102 & 122 \\
LSD 5\% & 6 & 6 \\
\hline
\end{tabular}

Trial 2

The data 'presented from this trial are for year two (1993/4),with the emphasis on sown species (tall fescue and white clover). Advance was the highest yielding cultivar in all seasons (Table 2). Its superiority over $\mathrm{AU}$ Triumph and Roa in summer and autumn and in annual grass production was significant at the $5 \%$ probability level. Clover growth tended to be more vigorous when grass growth was reduced. However, total sown species production for Advance was significantly greater than for Roa.

Table 2 Herbage production and composition.

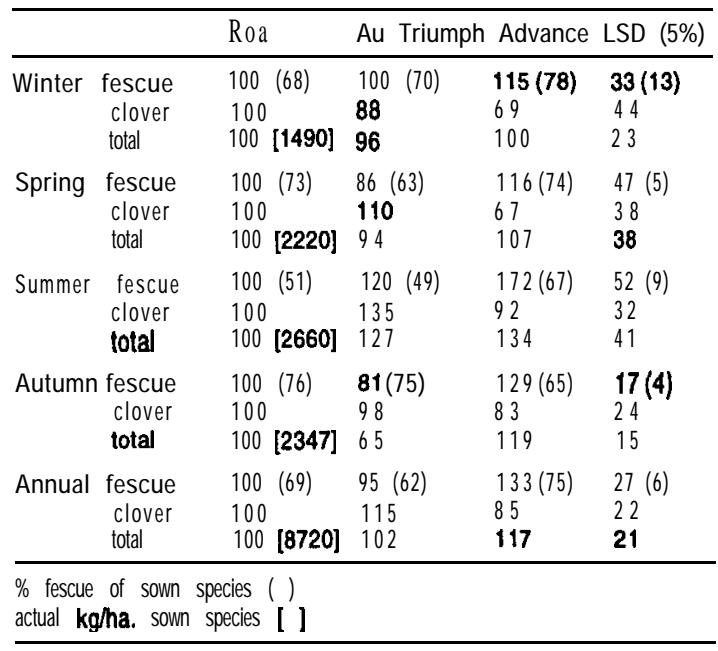

Table 3 Animal growth rates.

\begin{tabular}{lcc}
\hline & spring & sum/aut \\
\hline Roa & 100 & 100 \\
Au Triumph & 79 & 71 \\
Advance & 84 & 94 \\
LSD 5\% & 18 & 15 \\
\hline
\end{tabular}

\section{Trial 3}

Animal growth rates on Roa were significantly higher than on AU Triumph in spring, both Advance and Roa having a significant advantage over AU Triumph during summer and autumn (Table 3). Total grazing days for 
this trial (pure species) gave a 30\% and 25\% increase for AU Triumph and Advance over Roa. This resulted in an animal production per unit area index of Roa 100, AU Triumph 98, and Advance 112.

\section{Conclusions}

The combined effect of extra dry matter production plus improved animal performance of Advance gave a total production advantage of $14 \%$ over AU Triumph and 12\% over Roa in the first season of the Lincoln grazing trial. The results published in this paper clearly indicate that the aim of the plant breeder to breed a tall fescue cultivar with improved seedling vigour while maintaining warm-season quality has been met. With the release of Advance the place of tall fescue in New Zealand agriculture will be further enhanced.

\section{REFERENCES}

Brock, J.L. 1973. Effect of sowing depth and postsowing compaction on establishment of tall fescue varieties. NZ journal of experimental agriculture 1 : $1-14$.

East, R.; Koller, M.S.; Willoughby, B.E. 1982. Effects of Grass grub density on production on of tall fescue, cocksfoot and ryegrass sown with white clover. Proceedings of the 35th New Zealand Weed and Pest Conference: 82-85.
Easton, H.S.; Pennell C.G. 1993. Proceedings of the New Zealand Grassland Association 55:

Kain, W.M.; Slay, M.W.; Aitchinson, D.S. 1979. Evaluation of grass grub-plant interaction of grasses sown with and without white clover in Central Hawkes Bay. Proceedings of the 32nd New Zealand Weed and Pest Control Conference: 86-9 1.

MacFarlane, A.W. 1990. Field experience with new pasture cultivars in Canterbury. Proceedings of the New Zealand Grassland Association 52: 139- 143.

Milne,G.; Fraser, T.J. 1990. Establishment of 1600 hectares in dryland species around Oamaru/Timan. Proceedings of the New Zealand Grassland Association 52: 133- 137.

Prestidge, R.A.; Bodan, D.; van der Zipp, S. 1986. The effect of Argentine stem weevil on cocksfoot and tall fescue when sown with ryegrass. Proceedings of the 39th New Zealand Weed and Pest Control Conference: 33-37.

Woodman, R.F.; Doney, R.J.; Allan, B.F. 1990. Effects of drilling depth on seedling growth of seven pasture species. Proceedings of the New Zealand Grassland Association 52: 167- 170.

Wright, D.F.; Slay, M.W.A.; Hamilton, G.J.; Patterson, D.J. 1985. Tall fescue for finishing lambs and flushing ewes in Hawkes Bay. Proceedings of the New Zealand Grassland Conference 46. 173- 177. 